\title{
Agnieszka Kampka, Debata publiczna. Zmiany społecznych norm komunikacji, Oficyna Wydawnicza, Warszawa 2014, ss. 234
}

Niezależnie od tego, czy punkt widzenia determinuje spojrzenie językoznawcze, socjologiczne, filozoficzne czy kulturoznawcze, przedstawiciele każdej $\mathrm{z}$ tych dziedzin (i wielu innych) przejawiają zainteresowanie publicznym dyskursem, jego mechanizmami, regułami. Liczne analizy dotyczące złożonych relacji mediów i polityki, ról odgrywanych przez uczestników życia publicznego czy wpływu potoczności na komunikację wpisują się w ten nurt znakomicie. Namysł nad kwestiami związanymi z funkcjonowaniem w zmieniającym się społeczeństwie i kulturze owocuje nowymi publikacjami. Jedną z nich jest książka Agnieszki Kampki. Autorka, uznając, że niezbywalnym elementem funkcjonowania demokratycznego społeczeństwa jest debata publiczna, właśnie jej poświęca swoją wydaną w 2014 roku monografię. Zaznacza jednocześnie w podtytule, że pisać będzie o „zmianach społecznych norm komunikacji”.

Monografia Agnieszki Kampki składa się z pięciu rozdziałów, omawiających kolejno kontekstowe uwarunkowania oraz narzędzia debaty publicznej, jej społeczne funkcje, reguły i normy, wpływ zmian w mediach na jej kształt oraz (rozdział ostatni) kwestię wizualności debaty. Celem Autorki jest, jak sama zaznacza we wstępie, ,przedstawienie współczesnego, dynamicznego i wizualnego oblicza debaty publicznej" [Kampka 2014: 10]. Autorka deklaruje, iż podstawą dla jej książki stała się teoria retoryczna, a retorykę rozumie za Arystotelesem jako „sztukę wynajdywania tego, co przekonujące w danej sytuacji i danych okolicznościach" [Kampka 2014: 7-8]. Wskazuje, iż fundamentalne założenia sztuki retorycznej (wolność uczestników, celowe tworzenie sądów, dopasowanie mówiących do panujących warunków komunikacyjnych) odpowiadają całkowicie debacie publicznej [Kampka 2014: 8], i proponuje 
namysł nad wieloma właściwościami debaty, który uwzględniałby liczne, wąskie i szerokie, konteksty.

Zacznijmy od samego pojęcia, stanowiącego przedmiot monografii. Agnieszka Kampka proponuje uwzględnienie dwóch zasadniczych perspektyw, które mogłyby być zastosowane przy analizie debaty publicznej: wąskiej i szerokiej. Pierwsza z nich odnosi się do postrzegania debaty publicznej jako pojedynczego zdarzenia komunikacyjnego, druga, szeroka, pozwala patrzeć na debatę jako na proces. Dla pierwszej więc można by próbować uwzględnić aspekt genologiczny i określić kilka właściwości gatunkowych. Autorka koncentruje się raczej na wskazaniu, na jakiej płaszczyźnie między sporem a porozumieniem sytuuje się debata; określa, że debata nie ma prywatnego charakteru (tu można by uwzględnić zarówno kwestie tematyczne, jak i problem jawności, otwartości debaty, możliwość jej obserwowania przez obywateli), jest rodzajem dyskusji, która dotyczy spraw istotnych dla dużej grupy, spraw, jak to określa, „poważnych”, budzących kontrowersje. Zdaniem Autorki debata często jest związana z jakąś publiczną instytucją (choćby przez inicjatywę przez nią podjętą czy fakt, że w debacie biorą udział przedstawiciele takiej instytucji). Jak się wydaje, decydującą rolę odgrywa w tej charakterystyce perspektywa socjologiczna, cenna dla genologów, którzy mieliby jeszcze w tym względzie kilka kwestii do rozstrzygnięcia i uściślenia (choćby opisanie, obok cech typologicznych, odmian debaty i różnic między nimi). Wydaje się, że w literaturze $\mathrm{z}$ zakresu teorii tekstu brakuje wyczerpujących badań na ten temat.

Druga perspektywa definicyjna (szeroka, uwzględniająca aspekt procesualny) mogłaby, przy odpowiednich założeniach, zostać określona mianem dyskursywnej: wskazanie na rozciągnięcie w czasie, dynamiczność czy interakcyjność debaty jako procesu wprowadza na ścieżkę analizy dyskursu. Autorka nie zajmuje się rozpatrywaniem tej kwestii z perspektywy teoretycznej, ale w toku wywodu parokrotnie używa określenia dyskurs, poruszając kwestie związane choćby z zaangażowaniem obywatelskim czy - szerzej - relacjami społecznymi. To szerokie ujęcie będzie Autorce szczególnie przydatne w rozdziale ostatnim, poświęconym wizualności (o tym fragmencie monografii będzie jeszcze mowa dalej).

Agnieszka Kampka w pierwszym rozdziale, poza kwestiami definicyjnymi, analizuje przestrzeń debaty, jaką stanowi sfera publiczna: interesująco i klarownie ujawnia zmiany tego pojęcia w historii, wskazuje na problem dualizmu prywatne - publiczne, na rolę świadomości uczestników komunikowania, przywołuje istotne koncepcje na temat sfery publicznej (Jürgena Habermasa, Hannah Arendt, Johna Rawlsa, Ronalda Dworkina). W kontekście poszukiwań odpowiedzi na pytanie o zadania współczesnej publicystyki wartościowe 
wydają się rozważania na temat znaczącej roli różnic światopoglądowych dla kształtowania się złożonych wzorów interpretacji rzeczywistości [Kampka 2014: 30 i nn.].

Za równie ciekawe i inspirujące dla wszystkich, których interesuje komunikacja medialna, uznać można fragmenty dotyczące „głosu w przestrzeni”, czyli opinii publicznej. Wskazując na główne funkcje pełnione przez opinię publiczną (integracyjna, doradcza, kontrolna, deliberatywna), Autorka zauważa również jej istotny wpływ na nowe zjawiska społeczne oraz zaznacza, iż dopiero współcześnie, „od kilkudziesięciu lat opinia publiczna to tyle, co wyniki sondażu" [Kampka 2014: 34] (kontekst dotyczący olbrzymiej popularności sondaży w mediach czy zjawiska, o którym pisze Elisabeth Noelle-Neumann - spirali milczenia - jest wart namysłu, być może w roku wyborczym bardziej niż kiedykolwiek). Agnieszka Kampka wskazuje na rolę publicznych zgromadzeń w erze „przedmedialnej” oraz na problem osłabienia aktywności obywatelskiej w epoce mediów masowych. Ten wątek być może warto rozwinąć, by nie pozostawić czytelnika z wrażeniem, iż ta biegunowa tendencja (aktywni obywatele przekształceni w biernych odbiorców) jest jedynym możliwym kierunkiem. Interesującą próbą otwarcia tego tematu mogłoby być rozbudowanie zagadnienia alternatywnej opinii publicznej czy zasygnalizowanie już w tym miejscu (Autorka czyni to w kolejnych rozdziałach) sporej roli internetu i kultury popularnej w debacie publicznej.

Inspirujące mogą być uwagi dotyczące uczestnictwa w debacie publicznej: pozycja obserwatora i jego wpływ na kształt debaty, zmiany w warunkach odbioru debaty, wreszcie fundamentalna kwestia dotycząca funkcji rytualnej udziału w debacie (np. problem wykluczenia czy przełamywania nierówności). Innym istotnym wątkiem, rozpatrywanym w kontekście rozważań o uczestnikach, jest legitymizacja głosów w debacie - kwestia wartości głosów oraz ważności osób mówiących. Agnieszka Kampka [2014: 54] zauważa, że „współczesna kultura ceni ekspertów" i wskazuje (za Theo van Leuweenem) najczęściej wymieniane źródła legitymizacji (autorytet, moralna ocena, racjonalność, narracja wykorzystująca mit). Tym ogólnym konstatacjom warto by się przyjrzeć i rozważyć choćby relację między autorytetem a ekspertem, ekspertem a naukowcem, wreszcie kwestię ról symbolicznych i dyskursywnych, kluczowych dla rozpatrywania zagadnień związanych z perswazyjnością debaty publicznej. Rozwinięcie i pogłębienie tych zagadnień wydaje się istotne Autorka porusza tę problematykę w wielu miejscach monografii [por. Kampka 2014: 229 (indeks: debata - rola ekspertów)].

Agnieszka Kampka drugi rozdział książki poświęca w całości społecznym funkcjom debaty publicznej. Ważne staje się wskazanie, iż „funkcja danej 
debaty wyznacza normy, które ta debata powinna spełnić" [Kampka 2014: 64]. Autorka pokazuje, że debata to odkrywanie poglądów (od dialogów Platona po współczesność) - tu zwraca uwagę ulegający modyfikacji schemat dialogiczny (od lekcji dawanej przez mistrza aż po spory równych partnerów o zróżnicowanych poglądach). W obrębie tej funkcji Kampka sytuuje debaty wyborcze, wskazując na fakt, że uczestnictwo w debacie służy budowaniu wizerunku nie tylko współcześnie - Autorka przywołuje przykład sztuki konwersacji rozwijającej się w salonach literackich XVII-wiecznej Francji. Innymi funkcjami debaty zdaniem Agnieszki Kampki są: rozwiązywanie sporów, edukacja obywatelska, deliberacja (tu ciekawy wątek wspólnych i rozłącznych miejsc debaty i deliberacji), przedstawienie oferty (także w kontekście debat wyborczych).

Kolejna część monografii uzupełnia i częściowo również wyjaśnia perspektywę przyjętą wcześniej. Autorka zasadniczo (za Habermasem) uznaje debatę za proces etyczny i racjonalny, może więc charakteryzować reguły i normy, które powinny być przestrzegane. Rozważania na temat cywilizowanej debaty (civil conversation) w społeczeństwie obywatelskim stanowią zestaw ważnych reguł prowadzenia rozmów w danej kulturze. Autorka wspomina także o łamaniu zasad i o krępowaniu dialogu poprzez mowę nienawiści, a językoznawca w tym miejscu może czuć niedosyt - przydałby się choć akapit poświęcony temu budzącemu spore zainteresowanie pojęciu, wykorzystywanemu chyba zbyt często bez należytego objaśnienia przy charakterystyce publicznego dyskursu. Zasadniczo część poświęcona umiejętnościom komunikacyjnym wymagałaby pogłębienia. Autorka, akcentując ważną rolę kształcenia retorycznego, uczenia przez argumentowanie, wspomina o metodzie Daniela O'Keefe'a, a także przytacza koncepcję maksym konwersacyjnych Paula Grice'a, jednak w obu przypadkach czytelnik oczekiwałby oglądu poszerzonego, wykraczającego poza kwestie, które opisywane są w podręcznikach z zakresu pragmatyki językowej. Warto by również zaproponować namysł nad fragmentem poświęconym językowi debaty publicznej - gdy w jednym miejscu pojawiają się stwierdzenia: ,język debaty publicznej jest swego rodzaju powierzchnią, zewnętrzną warstwą debaty” [Kampka 2014: 130] czy ,język bywa pięknym lub brzydkim strojem nakładanym przez uczestników debaty" [Kampka 2014: 133], a w innym mowa jest o mocy sprawczej języka oraz o tym, że ,język tworzy naszą rzeczywistość” [Kampka 2014: 136], a „mówiąc działamy” [Kampka 2014: 137], to uderza swoista nieprzystawalność koncepcji i perspektyw. Ten rzeczony „brzydki strój” to przecież nie tylko „niechlujstwo językowe” czy agresja werbalna polityków, o których wspomina Autorka (o języku polityki pisało tak wielu ważnych badaczy, że nie sposób przywołać ich w tym miejscu). Wydaje się, że korzystniejsze dla tekstu byłoby niewyodrębnianie frag- 
mentu dotyczącego języka debaty poza kwestie związane z umiejętnościami komunikacyjnymi.

W części monografii poświęconej zmianom w przestrzeni medialnej istotne są wątki związane z rolą odbiorców jako uczestników debaty, zjawiskiem widzotariatu (viewertariat) oraz mediatyzacji polityki. Czytelnik na pewno byłby wdzięczny za szersze wyjaśnienie różnic i podobieństw między zjawiskami tabloidyzacji oraz inforozrywki [Kampka 2014: 158-160] czy za pogłębiony ogląd kryteriów, jakie powinna spełnić informacja, by mogła ukazać się w mediach [Kampka 2014: 172]. Zabrakło (ciekawego i ważnego w kontekście debaty publicznej) wątku o mediach jako pośrednikach - przytaczających głosy innych, wybierających z wielogłosu to, co uważają za ważne/atrakcyjne/ relewantne.

Ostatni rozdział Autorka zatytułowała Wizualność debaty publicznej. Przyjmuje w tej części bardzo szeroką definicję analizowanych zjawisk: zarówno debaty publicznej, jak i samej kwestii wizualności. Bez wątpienia ciekawymi wątkami są zagadnienie kultury zagłuszania [Kampka 2014: 187 i nn.] czy kwestia odwołań w argumentacji politycznej. Agnieszka Kampka wskazuje, że kiedyś były to historia, prawo, mitologia, dziś - kultura popularna. Zastanawiać może samo pojęcie wizualności oraz synonimiczne wykorzystywanie określenia obrazowość. Bez wątpienia Autorka częściowo nawiązuje do koncepcji homo videns, opisywanej przez Giovanniego Sartoriego (kwestii redukowania kompetencji językowych oraz coraz większych trudności w operowaniu pojęciami abstrakcyjnymi) - jednak obrazowość (co należy zaznaczyć) niekoniecznie musi odwoływać się tylko i wyłącznie do oddziaływania na zmysł wzroku. Zagadnienie dotyczące sztuki zapamiętywania poprzez asocjacje znane było od starożytności, podobnie jak kwestie związane z porównaniem jako skutecznym środkiem perswazji. Wydaje się, że Autorka nie we wszystkich miejscach odwołuje się do wizualności i elementów wizualnych, a do obrazowości właśnie, choć niewątpliwie rozważania dotyczące obywatelskiej kompetencji wizualnej czy estetyzacji życia politycznego są trafne.

Książka Agnieszki Kampki jest napisana lekko, przejrzyście, Autorka wykazuje się umiejętnością docierania do sedna w sposób nieobciążający nadmiernie tekstu spiętrzeniami terminologicznymi czy zawiłością frazy. Cenne nie tylko dla teoretyków, ale również dla praktyków publicznego dyskursu (polityków czy publicystów) są liczne przykłady, często zaczerpnięte ze współczesnego życia politycznego, lub fikcyjne casusy, wskazujące na meandry funkcjonowania w społeczeństwie obywatelskim.

Agnieszka Kampka [2014: 66] pomieściła w swej monografii kilka istotnych wątków, mogących stać się punktem wyjścia dla kolejnych tekstów - przy- 
kładem może służyć choćby stwierdzenie: „Niezbędnym warunkiem powodzenia debaty jest unikanie wcześniejszych założeń, zgoda na kwestionowanie". To ujęcie mogłoby zostać z powodzeniem rozwinięte w kontekście zasad sztuki publicystycznej, zestawione choćby z koncepcją Michała Głowińskiego [2011: 90 i nn.], piszącego o polifoniczności jako jednym z warunków dyskursu publicystycznego. W podobny sposób inspirujące są inne stwierdzenia - wytropione przez uważnego czytelnika mogą stać się przyczynkiem do dyskusji o publicystyce i jej współczesnej kondycji, o różnorakich aspektach dyskursu publicznego. Taka dyskusja, zainspirowana lekturą monografii Agnieszki Kampki, a podjęta przez przedstawicieli kilku dyscyplin humanistycznych, mogłaby bez wątpienia zaowocować... wzbogaceniem debaty publicznej na ten temat.

Agnieszka Kula

\section{Bibliografia}

Głowiński Michał (2011), Realia, dyskursy, portrety. Studia i szkice, Universitas, Kraków.

Kampka Agnieszka (2014), Debata publiczna. Zmiany spotecznych norm komunikacji, Oficyna Wydawnicza, Warszawa. 